Revue interdisciplinaire des études canadiennes en

France

$85 \mid 2018$

Le Canada, refuge américain?

\title{
Colonial policies and propaganda: the making of British North America as an anti-republican refuge after the War of Independence (c. 1783-1815)
}

Politiques coloniales et propagande : la construction de l'Amérique du nord britannique comme refuge antirépublicain après la Guerre d'Indépendance (1783-1915)

Alice Lemer-Fleury

\section{(2) OpenEdition}

\section{Journals}

Electronic version

URL: http://journals.openedition.org/eccs/1425

DOI: $10.4000 /$ eccs. 1425

ISSN: 2429-4667

\section{Publisher}

Association française des études canadiennes (AFEC)

Printed version

Date of publication: 31 December 2018

Number of pages: $29-48$

ISSN: 0153-1700

\section{Electronic reference}

Alice Lemer-Fleury, « Colonial policies and propaganda: the making of British North America as an anti-republican refuge after the War of Independence (c. 1783-1815) », Études canadiennes / Canadian Studies [Online], 85 | 2018, Online since 01 December 2019, connection on 02 December 2019. URL: http://journals.openedition.org/eccs/1425; DOI : 10.4000/eccs. 1425 


\title{
Colonial policies and propaganda: the making of British North America as an anti-republican refuge after the War of Independence (c. 1783-1815)
}

\author{
Alice LEMER-FLEURY \\ Université de Nantes ${ }^{1}$
}

\begin{abstract}
As thousands of Loyalists sought shelter in British North America after the American Revolution, this article is an attempt to assess the reaction of the mother country to this wave of refugees. Through the study of the colonial correspondence of the British Secretaries of State, it examines the determination of the British government to turn the British North American colonies into loyalist haven. It explores how this process set trends and patterns in British colonial policy that soon consolidated into an antirepublican design aimed at protecting the remaining British colonies of North America from the influence of the United States.
\end{abstract}

Alors que la Révolution américaine amena des milliers de Loyalistes à se réfugier en Amérique du Nord britannique, cet article propose d'étudier la réaction de la métropole à travers l'étude de la correspondance coloniale des secrétaires d'État chargés des colonies. Il examine la détermination de Londres à créer un havre loyaliste en Amérique du Nord britannique et montre comment cet objectif façonna la politique coloniale britannique. Cet article met en évidence les traits et caractéristiques de la politique coloniale britannique après la Révolution américaine et explore la façon dont ils se sont rapidement consolidés en un dessein antirépublicain visant à protéger les colonies britanniques de l'influence des États-Unis.

In 1776, the thirteen American colonies declared themselves independent and rejected the imperial authority of King George III. During the ensuing conflict, the Continental Congress tried to rally the provinces of Quebec and Nova Scotia to their rebellion against the Mother Country. The rebel colonies sent emissaries, had letters circulated in the province of Quebec and tried to take the cities of Montreal and Quebec in 1776. In spite of these efforts, the Frenchspeaking Canadiens of the Province of Quebec did not join the rebellion. In Nova Scotia, the American raids on the coasts, as well as the strong British military presence in the colony, did not encourage the English-speaking population to rally the Revolution either (WRONG 1968, 278-320; LANCTOT 1967, 27-29, CONRAD AND HILLIER 2010, 93-95). The annexation of Quebec was also one of the aims of the American diplomats during the peace negotiations in Paris in 1782 (STUART 1988, 10-26). However, instead of becoming part of the new republic in the making, Quebec and Nova Scotia became a refuge for thousands of American colonists who remained loyal to the British crown. About 60,000 "Tory" refugees left the United States between 1775 and 1784 - around half of them, including 3,000 black Loyalists, found shelter in Nova Scotia, whilst about

\footnotetext{
${ }^{1}$ Centre de Recherches en Histoire Internationale et Atlantique (EA 1163)
} 


\section{ALICE LEMER-FLEURY}

6,000 made their way to Quebec (KNOWLES 2006, 36; JASANOFF 2010, 46). One of the most important contributions of recent research has been to challenge the idea that these Loyalist waves of refugees were a homogenous group of white, Protestant, Yankee-hating Tories (POTTER 1983, 172; KNOWLES 1997; SHAMA 2006; JASANOFF 2011, BANNISTER and RIORDAM 2012, 20). They were white, black or native Americans, rich and poor, hostile or favourable to imperial reform, but all had in common their attachment to the King, their loyalty to the British Crown and their rejection of the American republic in the making (POTTER 1983, 107; JASANOFF 2001, e703, e3857, e4270).

Essential though they are, those contributions essentially focus on the North American perspective and on the feeling of disappointment and/or betrayal the Loyalists felt with the signing of the Treaty of Paris in 1783, as the British peace negotiators only managed to secure the promise that "Congress shall earnestly recommend it to the legislature of the respective states to provide for the restitution of all estates, rights, and properties, which have been belonging to British subjects" (Treaty of Peace 1783, Article V) and failed to protect their Native American allies from further American expansion (JASANOFF 2010, 46). After 1783, although historians concur in underlining the authoritarian, even despotic, attitude of the Mother Country, they tend to treat the role of London as peripheral - as such, they also reinforce the mistaken, albeit long-enduring, impression that the British government neglected its North American colonies. ${ }^{2}$ Colonial officials, most notably the Governor and Lieutenant Governors, did play an essential part in shaping and, more conspicuously, in implementing colonial policy, but they were directly answerable to the King and his ministers, had to follow the directives and instructions which were regularly sent from London ${ }^{3}$ and worked under the close scrutiny of the Secretary of State in charge of the colonies. ${ }^{4}$ The Secretary of State did seek the advice of most of those who had an

\footnotetext{
2 C.A. Bayly (1989) underlines the interventionist and authoritarian character of British imperial policy after 1783, but North America is only a minor part of his research. Studies which focus on London's policy for the North American colonies are rather rare, and tend to present the colonial policy of Britain as neglectful (TAFT MANNING 1933) or as little more than mere "reactions to outside pressure" (MARSHALL 2015, 129).

3 The colonial correspondence for British North America shows that British ministers throughout the years 1783-1815 sent, on a low average, three letters a month to the Governor and Lieutenant Governors, to which should be added the countless circulars, private letters, and official letters sent to other officials or members of the royal family stationed in the colonies.

${ }^{4}$ The minister in charge of the colonies was the Home Secretary until 1801 when colonial affairs were moved to the Secretary of State for War and the Colonies. The holders of these offices were: Lord Sydney (1783-1789), Lord Grenville (1789-1791), Henry Dundas (1791-1794), the Duke of Portland (1794-1801), Lord Pelham (1801), Lord Hobart (1801-1804), Lord Camden (1804-1805), Lord Castlereagh (1805-1806, 1807-1809), William Windham (1806-1807), Lord Liverpool (1809-1812) and Lord Bathurst (1812-1827)
} 


\section{COLONIAL POLICIES AND PROPAGANDA: THE MAKING OF BRITISH NORTH AMERICA AS AN ANTI-REPUBLICAN REFUGE}

interest in the North American colonies (such as the colonial officials on the spot, British-based merchants or the Lords of Trade and Plantations), but his office remained the centre of power and decision-making for the colonies (NELSON 1969; YOUNG 1961).

This article therefore primarily focuses on the role of London in the wake of the War of Independence. By 1783, the American Revolution had highlighted the failures of British colonial policy as well as the dangers of republicanism, whilst the Treaty of Paris both led to the collapse of the Shelburne ministry ${ }^{5}$ and sparked unprecedented waves of refugees, who were taken care of by the British authorities. Through the study of the decisions made at Whitehall, this article is an endeavour to determine whether there was a decisive attempt of the British government to build an anti-republican and even an anti-American refuge in North America. To what extent did the aim of making British North America a refuge from the republican United States shape British colonial policy? What did the British government do to ensure that the British North American colonies would remain safe from the influence of their southern neighbours and their republican ideas?

This article is primarily built on the study of the official correspondence of the Secretaries of State in charge of the colonies. It shows that British colonial policy towards the Loyalists refugees was at first mostly reactive though there was, from the very beginning, a strong determination to create a refuge from the United States in the British North American provinces. It demonstrates how the decisions implemented by London turned out to be a fully comprehensive imperial scheme and set trends that would become characteristics of British colonial policies in the coming decades. It eventually shows that those policies consolidated into a pro-active anti-republican design aimed at developing the British North America whilst preventing another revolution.

\section{The making of British North America into a refuge from the United States}

In the wake of the American Revolution, and more particularly after the signing of the Treaty of Paris and the recognition of the Independence of the thirteen colonies by Great Britain, the American settlers who remained loyal to the British Crown found themselves under the necessity to leave the United States. London had to design evacuation and relief plans for about 40,000 "Tory" refugees to flee up north, to the British provinces of Nova Scotia and Quebec

\footnotetext{
${ }^{5}$ The issue of Loyalist compensation "helped bring down the Shelburne government" (JASANOFF 2011, e2408).
} 


\section{ALICE LEMER-FLEURY}

(KNOWLES 2006, 36). Thus began the turning of British North America into a refuge for those who fled the United States and republicanism. London's reaction to the wave of refugees was a set of exceptional and short-term decisions that would eventually change and shape British colonial policy.

\section{Reactive policy: exceptional decisions and changes in colonial priorities}

Just as such an influx of war refugees was unprecedented in the history of the British Empire, the building of British North America into a refuge for the Loyalists led to the implementing of an exceptional set of decisions and a "remarkably comprehensive relief effort" (JASANOFF 2010, 46). The government had the Royal Navy evacuate Loyalists and their families, demanded that colonial officials do everything in their power to help the refugees and had them provided with food, land, tools and, later on, compensation (Additional instructions, 16 July 1783, RCCA 1904, 264-265; North to Haldimand 24 July 1783, Q26A, 410). The granting of land, tools and provisions was not a novelty: London had already implemented such policies in North America for disbanded soldiers after the Seven Years War. However, turning British North America into a refuge from the new American republic not only shifted the attention of the British government towards this end, it also, temporarily, changed the priorities of colonial policy. Though ministers of the Crown were constantly preoccupied if not obsessed - with limiting colonial expenses, the Mother Country did not hesitate to spend millions of pounds as it directed colonial policy to helping the loyal subjects of the King. ${ }^{6}$ For this end, they could count on the unfailing support of Parliament whose members endlessly praised those "loyal and excellent subjects" and systematically voted funds to provide for their needs (MARSHALL 2015, 123; The Parliamentary History, vol. xxiii 1782-1783, 1042-1045, vol. xxvii 1788-1789, 506-507, 610-620; The Parliamentary Debates, vol. iv 1805, $675)$.

Britain helped the Loyalists because it "had a moral responsibility" to do so (JASANOFF 2011, e2473). This notion of duty meant that the King's bounty was to be extended to all the Loyalists, without distinction - another exceptional element in the colonial policy of the late $18^{\text {th }}$ century. During the American Revolution, black slaves who joined the British side had been promised land and freedom for their loyalty - the 3 to 5,000 black refugees who arrived in Nova Scotia were thus entitled to the same provisions and privileges as the white Loyalists. They were however not treated on an equal footing by the colonial

\footnotetext{
${ }^{6}$ The British government spent about 3 million pounds for the Loyalists, which corresponds to 400 millions in today's money (JASANOFF 2008, 215).
} 


\section{COLONIAL POLICIES AND PROPAGANDA: THE MAKING OF BRITISH NORTH} AMERICA AS AN ANTI-REPUBLICAN REFUGE

authorities, which led Thomas Peters ${ }^{7}$ to petition Secretary Dundas in the name of the black Loyalists of Nova Scotia. The Secretary of State's answer was severe and unequivocal: he enjoined Lieutenant Governor Parr to "give directions that the full proportions of lands promised to them may immediately be located, in a situation as advantageous as may make them some atonement for the injury they have suffered by this uncountable delay." It was utterly unacceptable for London that any group of Loyalists, whatever their skin colour, should not benefit from the King's bounty - and Dundas saw to it (Dundas to Parr, No 11, 6 Aug. 1791, A116, 239-240).

Similarly, the British North American provinces were used as a refuge for the indigenous peoples who had fought on the side of the empire and were being pressured by land-hungry American settlers, like the Mohawk. This was part of the British strategy to keep the support of the indigenous people of the Great Lakes and ensure that the fur-trading posts in this area remain under British control, by assuring "those unfortunate People that they will find an asylum within His Majesty's Dominion, should they be inclined to cross the lakes and put themselves under our Protection" (Sydney to Haldimand, 8 Apr. 1784, Q23, 61).

Although the black Loyalists eventually resettled in Sierra Leone (JASANOFF 2011, passim.) and although London did not keep all of its promises to the indigenous peoples (ALLEN 1992, passim.), the making of a "comfortable asylum" (Sydney to Campbell, 8 Mar. 1785, A107, 19) was designed for all the refugees, regardless of the colour of their skin.

London's determination to turn British North America into a refuge from the United States was not restricted to early Loyalists. In 1785, Whitehall authorised Lieutenant Governor Hope to accept into Quebec the American migrants "who do not pretend to have been sufferers in defence of the British Laws and Government but are actually sufferers under the ruinous and arbitrary laws and Constitution of the United States" (Sydney to Hope, 22 Aug. 1785, Q25, 39-41). Those settlers, who were not "bona fide Loyalists", were not entitled to the King's bounty (Dundas to Simcoe, 2 Oct. 1793, Q278A, 27) but they could benefit from some of the advantages of British North America over the United States, mainly cheap lands and, so was the British Ministry's point of view, political peace and order. Quaker migrants were also dispensed from taking the

\footnotetext{
${ }^{7}$ Thomas Peters was a slave in North Carolina who joined the British forces after Lord Dunmore's proclamation of 1775. Peters, who was promoted sergeant, was evacuated to Nova Scotia in 1784 (JASANOFF 2011, e1093). See also WALKER James W. St G. "Thomas Peters". Dictionary of Canadian Biography online. 1979-2019. http://www.biographi.ca/en/bio/peters thomas 4E.html
} 


\section{ALICE LEMER-FLEURY}

oath of allegiance to the British Crown (Dundas to Dorchester, 28 Nov. 1794, Q77A, 97). In other words, ministers in London made decisions to make resettlement easier for all those who fled or left the United States.

\section{Shaping British colonial policy: trends and patterns}

There was a strong determination in London to turn British North America into a refuge from the United States. The decisions made in 1783-1784 were all-encompassing but they were primarily an immediate response to the need to provide for the Loyalists, rather than a set of policies planned for the long-term. Nevertheless, the policies implemented in the wake of the American Revolution for the American refugees had a profound, long-lasting impact on the ways London dealt with its North American colonies and shaped the colonial designs of the coming decades.

The end of the War of Independence and the arrival of the Loyalists in Quebec and Nova Scotia almost immediately transformed the way the Mother Country saw its colonies, mostly because they were now the only British possessions on the American continent and the home of thousands of British-born or at least English-speaking settlers. Lord Sydney made it extremely clear to Lieutenant Governor Parr as early as May 1784 when he wrote that "the few Provinces which we have now remaining on that side of the Atlantic, of course increase in consequence to this Country" (Sydney to Parr, 29 May 1784, A105, 38). The King's ministers were also confident that the immense expenses consented to provide for the refugees would soon bear fruit. In the colonial correspondence, they regularly expressed their satisfaction and that of the King at the expected "flourishing state" of the new settlements in Quebec (Sydney to Hope, 6 Apr. 1786, Q26A, 438) and Nova Scotia, with Sydney famously prophesising:

I trust from all the accounts I have [that the province of Nova Scotia] will soon be in a flourishing State and that those unfortunate People who have been obliged to take refuge in it will find a comfortable Asylum and will in a short time be the envy of the Citizens of the United States. (Sydney to Campbell, 8 Mar. 1785, A107, 19)

In other words, London was not only determined to make British North America a refuge from the United States, it also aimed at turning the provinces into a better version of the former thirteen colonies. The ways to achieve his aim and further the development of British North America were still rather blurry and undefined when Sydney wrote, but it soon affected the manner the British government dealt with its North American colonies. 


\section{COLONIAL POLICIES AND PROPAGANDA: THE MAKING OF BRITISH NORTH AMERICA AS AN ANTI-REPUBLICAN REFUGE}

Indeed, as London invested large sums of money to provide for the Loyalists with the hope that it would also be useful for the development of British North America, the ways the measures for the Loyalists were implemented foreshadowed the more authoritarian and supervised method Britain would use to manage her North American possessions in the following decades. The instructions drafted in London were precise but the (daunting) task of implementing them fell on colonial officials on the spot. At first, the British Ministers gave a large degree of executive liberty to the governors. In 1783 for example, Lord North acknowledged to Governor Haldimand that, "however full and clear the Instructions may be, I am sensible that much must be left to your discretion and prudence, upon which I am persuaded I may fully depend" (North to Haldimand, 24 Jul. 1783, Q26A, 411). At the beginning of the secretaryship of his successor, Lord Sydney, the same kind of confidence in the British officials in North America is to be found. The Secretary and his Under-Secretaries simply, though constantly, insisted that the colonial authorities take good care of the Loyalists. ${ }^{8}$ Yet, the ways the measures were to be implemented eventually took up a large share of the colonial correspondence in the 1780s and the early laisserfaire was soon abandoned to give way to a closer scrutiny, as Sydney and his successors attentively monitored the Loyalist policies, from the granting of land to the distribution of relief articles (Sydney to Carleton, 15 Dec. 1785, RG7 G8B; Sydney to Parr, 20 Apr. 1786, A108, 104-105; King to Clarke, 2 Jul. 1792, Q77A, 22). The way Whitehall managed the Loyalist crisis is thus one of the examples that shows how the British imperial stance evolved from a type of "salutary neglect" to an authoritarian, though caring, control of the colonies.

The making of a refuge in British North America also set patterns influenced by this desire to temper authoritarianism with benevolence. The plans designed in the 1780s for the American Loyalists were used in the 1790s and 1800 s for other refugees and exiles. For instance, in the early 1790s, the King's desire to create a shelter for those who fled republicanism was extended to French refugees. The French Revolution led thousands of aristocrats, clergymen and royalists to leave France. Some found their way to Britain, where the government offered them to settle in Quebec, now Lower Canada. They were provided with passage, provisions, tools and lands "in the proportion granted to American

\footnotetext{
${ }^{8}$ See for instance: Sydney to Haldimand, 8 Apr. 1784, Q23, 61; Sydney to Parr, 7 June 1784, A105, 38; Sydney to Parr, 5 Oct. 1784, A106, 16; Sydney to Governor of Nova Scotia, 6 Jan. 1785, A107, 12; Sydney to Hamilton, 27 Apr. 1785, Q24, 212; Napean to Hope, 5 Aug. 1785, Q25, 33; Napean to Hope, 22 Aug. 1785, CO42/17, 94; Sydney to Carleton; 27 Aug. 1785, RG7 G8B, volume 1.
} 


\section{ALICE LEMER-FLEURY}

Loyalists" (Portland to Russell, No10, 3 July 1798, Q278A, 148). ${ }^{9}$ Though not fleeing republicanism, it may also be noted that, still in the 1790s, the British government decided to use Nova Scotia to shelter the Maroons exiled from Jamaica by Governor Balcarres (Portland to Wentworth, No 17, 13 June 1796, A123, 90-91). Over the following decades, the Canadian colonies would also be used to welcome growing numbers of dispossessed Highlanders (Sydney to Parr, 5 Oct. 1784, A106, 14-16; Sullivan to Caren, Esq. Home Office, 23 Mar. 1804, TNA, HO42/74/241-242; Bathurst to Prevost, No 38, 18 Aug. 1813, Q125A, 170171). In the study of the decisions made in London, it appears that there was a strong will to use British North America as an asylum for all those who were compelled to leave their homeland - using the model set after the arrival of the early American refugees as "granting inclusive protection in return for loyalty to the Crown", which became a "pillar" of British policy (JASANOFF 2010, 56).

There was, therefore, an indubitable determination in London to turn British North America into a refuge. The policies implemented for the American refugees set trends, patterns and models that shaped colonial policy. It also led London to view its North American possessions differently and to manage them in a more authoritarian manner - all of which would become characteristic of the way the British government decided to develop, improve and reform British North America in the following decades.

\section{Policy and propaganda: the making of an anti-republican haven}

The study of the colonial correspondence shows that the enormous expenses consented to accommodate the American refugees and the trends in the immediate aftermath of the War of Independence soon consolidated into a longterm pre-emptive and proactive policy to ensure that British North America would remain safe from American, and French, republicanism.

This meant that once the Loyalists were settled, ministers endeavoured to develop British North America in a way that would keep it closed up from the influence of Americans and their republican ideas. The plans designed in London for this end were often in contradiction with the opinion of colonial officials in the colonies, thus showing the centrality of the British government in shaping policies for British North America.

\footnotetext{
${ }^{9}$ See also: King to Dorchester, 30 Nov. 1792, Q77A, 46; Dundas to Wentworth, No 3, 12 Dec. 1792, A117, 291; Portland to Russel, No 10, 5 July 1798, Q278A, 148-149; Portland to Hunter, No 1, 11 June 1799, Q278A, 183-184 and FOURNIER, 1995, 32
} 


\section{COLONIAL POLICIES AND PROPAGANDA: THE MAKING OF BRITISH NORTH AMERICA AS AN ANTI-REPUBLICAN REFUGE}

\section{Authoritarian control of the colonies under the guise of liberality}

Ministers first started with political reforms for British North America. The changes implemented after the arrival of the Loyalist refugees followed a distinctive pattern: in order to make sure that the colonies would be preserved from a levelling spirit or the spreading of republican ideas, London reformed the system of governance to make it more authoritarian and more closely monitored by the Mother Country. This, however, was done under the guise of liberality.

In a move that might seem contradictory, the ministers of William Pitt first decided to give a degree of popular representation in the colonies. The British government granted representation to the colonists settled in the inland of Nova Scotia through the creation of the province of New Brunswick in 1784 (BT5, volume 2, 15 June 1784, 3-4) and later on in the Province of Quebec, which was divided into Upper and Lower Canada in 1791, with a system that resembled that of the Mother Country. In the meantime, it reduced the powers of Lieutenant Governors and nominated a Governor General with "extensive powers" (Napean to Hope, private, 3. Sept. 1785, CO42/17, 113; Sydney to Hope, 6 Apr. 1786, Q26A, 440).

Officials in the colonies were also determined to keep the provinces under their command free from any "innovation" (as they called reforms) that might endanger their authority and the omnipotence of imperial control. They thus tended to oppose elected assemblies and saw demands for reforms as a "republican threat" (Dorchester to Sydney, 8 Nov. 1787, Q28, 181; GREENWOOD 1993, e284; DUCHARME 2010, 51-54). London, however, viewed the situation differently and more subtly. Indeed, though they were loyal to the King, the American refugees were also used to being represented in assemblies and considered it their birthright as Englishmen, and they soon began to make demands for a representative form of government. The King's ministers decided to use this it to their own advantage. The reforms in the Maritimes and the Canada Act of 1791 were presented as a proof of the King's benevolence, and aimed at strengthening the attachment of the colonists to the Crown. This is what Lord Sydney explained to the Lieutenant Governor of Nova Scotia for the creation of New Brunswick:

The King trusts that this measure may not be considered as the effect of any other cause than that of His Gracious disposition to contribute, by every possible means, towards the general convenience and comfort of His 


\section{ALICE LEMER-FLEURY}

faithful and loyal subjects who have taken refuge in these parts of His Majesty's dominions (Sydney to Parr, 28 May 1784, A105, 37).

The British government emphasized the fact that reforms were not the consequence of yielding to popular pressure. On the contrary, the colonial authorities were instructed to present them as an act of liberality of the King towards his loyal colonies. Furthermore, everything had to be done to make sure that the new colonists would not accumulate grievances against the Crown and reinforce the loyalty of the newcomers. In New Brunswick, Sydney demanded that Lieutenant Governor Carleton convene an assembly as soon as possible after the creation of the province (Sydney to Carleton, 21 Aug. 1784, RG7 G8B) while in Nova Scotia, Lieutenant Governor Parr had to "impress" settlers who might show some discontent with the "liberality" of the King (Sydney to Parr, 7 Jun 1784, A105, 46).

It must be noted that most decisions made by London over the period 1783-1815 aimed at strengthening the loyalty of the British North American colonists. Every single Secretary of State of the period insisted that colonial officials highlight the "liberal" disposition of the King towards his North American subjects and make His Majesty's desire to promote "their prosperity and happiness" known to them. The imperial propaganda in British North America constantly underlined that the interests of the Crown and those of the colonies were "inseparable". ${ }^{10}$ A wide range of initiatives was used to foster and strengthen the loyalty of the colonists, from the visits of Prince William Henry in Quebec in the late 1780s and that of Prince Edward in Nova Scotia in the 1790s (Sydney to Dorchester, 8 Nov. 1787, Q59B, 29; Dundas to Wentworth, No 18, 7 May 1794, A120, 110) to the promotion of education and Anglicanism. All the efforts made by the British government to spread British values were used to underline the benevolence of the King and his satisfaction towards his North American subjects. For example, the founding of a college in Montreal in 1815 was presented as a "reward" for the loyalty of Lower Canada during the war

\footnotetext{
${ }^{10}$ See for instance: Sydney to Haldimand, 8 Apr. 1784, Q23, 58-60; Sydney to Parr, 7 June 1784, A105, 46-47; Sydney to Carleton, 19 Apr. 1786, RG7 G8B, volume 1; Grenville to Dorchester, No 9 , 20 Oct. 1789, Q59B, 110; Grenville to Parr, No 4, 5 June 1790, A114, 195-196; Dundas to Clarke, 3 Feb. 1793, Q77A, 55; Dundas to Dorchester, 15 Feb. 1794, Q77A, 114; Portland to Dorchester, No 14, 8 May 1795, Q77A, 196; Portland to Simcoe, No 6, 9 May 1795, Q278A, 72; Portland to Russel, No 1, 13 Dec. 1796, Q278A, 111; Portland to Hunter (separate), 9 Oct. 1799, Q278A, 196; Hobart to Milnes, No 10, 6 Aug. 1802, Q78A, 198; Hobart to Hunter, No 15, 1 Dec. 1802, Q293A, 30-31; Camden to Hunter, 22 June 1805, Q293A, 75; Castlereagh to Craig, No 14, 31 Dec. 1808, Q97A, 108; Bathurst to Sherbrooke, No 15, 9 Dec. 1812, A148, 35.
} 


\section{COLONIAL POLICIES AND PROPAGANDA: THE MAKING OF BRITISH NORTH AMERICA AS AN ANTI-REPUBLICAN REFUGE}

against the United States (Bathurst to Drummond, 30 Dec. 1815, Q136A, 157159).

Such avowed benevolence and liberality were actually used to conceal the increasingly authoritarian nature of London's imperial policy. The analysis of the colonial correspondence shows that assemblies and a degree of popular representation were granted in order to kill demands for more radical reforms in the bud. Lord Grenville made this absolutely clear in a letter to Governor Dorchester in 1789 about the constitutional reform in Quebec:

I am persuaded that it is a point of true Policy to make these Concessions at a time when they may be received as a matter of favour, and when it is Our own power to regulate and direct the manner of applying them, rather than to wait 'till they shall be extorted from us by a necessity which shall never leave us any discretion in the form, nor any merit in the substance of what we give. (Grenville to Dorchester (private), 20 Oct. 1789, Q42, 92-94)

In other words, the aim of British policy, in granting reforms and representative institutions, was to better control the colonies. Besides preventing the spreading of ideas developed by reformers and radicals, Grenville also made sure that the lessons from the American Revolution were learnt. Indeed, republicanism was perceived as a "dangerous [...] North American malady" and London tried to avoid the mistakes that had led to the Declaration of Independence in the former colonies (GREENWOOD 1993, e1328-1349). For example, the power of the assemblies was limited: unlike the assemblies in the former thirteen colonies, they had "no power of the purse" and had thus no control over the emoluments of the colonial governors. With the creation of legislative and executive councils, Grenville hoped that a form of aristocracy, that would be both loyal and docile, would develop in the colonies and strengthen the power of the Crown (Grenville to Dorchester, No 2, 20 Oct. 1789, Q59B, 67-68). The Secretary of State also designed a system of Church and Crown reserves - which would create new sources of revenue once the lands reserved increased in value and were sold. These revenues would then be used for the civil establishment of the colonies, thus keeping it under the control of the Mother Country (and not that of the colonial assemblies). For Grenville, it was "a Measure, which, if it had been adopted when the Old Colonies were first settled, would have retained them to this hour in obedience and Loyalty" (Grenville to Dorchester, private and secret, 20 Oct. 1789, Q42, 92-94). In short, the reform of 1791 reinforced imperial control and, as Michel Ducharme puts it, was conceived as "un antidote au républicanisme” (DUCHARME 2010, 57-58, 60; LAUDY 1995, 76-88). 


\section{ALICE LEMER-FLEURY}

After the implementation of those reforms, ministers in London had to leave immediate decisions and responses to republican threats to colonial officials on the spot. This menace came both from the United States and from France via the United States and was especially strong in Lower Canada (memorial for Mr. Pitt, CO42/18, 144). For instance, in the early stages of the Revolutionary Wars, in 1794, Citizen Edmond Genêt (the French minister to the United States) started to send agents to stir up discontent in Lower Canada so that they might rebel against the King. Dorchester's response was swift and strong: he issued two proclamations that enabled him to expel foreigners, had the assembly pass an Alien Act that restricted the rights of foreigners, suspended the habeas corpus and gave an "elastic definition" of sedition (GREENWOOD 1993, e2526). These decisions were highly approved by the Secretaries of State Dundas and Portland (Dundas to Dorchester, 11 May 1794, Q77A, 126; Portland to Dorchester, No 5, 4 Oct. 1794). Three years later, Genêt's successor, Citizen Adet, sent the American David McLane to the Canadas with a similar plan of subverting British North America, promising to free Canadians from the "tyranny" of the King. When McLane was arrested, the Duke of Kent expressed his belief that "an example in such an affair cannot be too quick or too striking". The colonial officials listened: McLane was sentenced to death and quartered - a decision that was approved by Portland (GREENWOOD 1993, ch. 7; Portland to Prescott, 20 Jan. 1798, Q78A, 2-3).

Leaving some degree of executive liberty to colonial officials to deal with the republican threat did not mean that the Secretaries of State did not continue to keep the colonies closely monitored. Ministers usually sent directives to colonial officials and intervened when the situation seemed to worsen - London was reactive when it was felt the security and internal tranquillity of the colonies might be at risk. For example, all the Secretaries of State wanted colonial officials to ensure that "harmony", "mutual cooperation", "diligence" and "unanimity" prevail at all times among the Governor, his councils and the assembly. ${ }^{11}$ These demands were sometimes not sufficient and ministers had members of the councils in the Canadas and Nova Scotia suspended or even ordered to leave the country when their behaviour was considered seditious (Windham to Wentworth, No 1, 8 May 1806, A138, 90; Castlereagh to Gore, No 2, 19 June 1807, Q293A, 112; Castlereagh to Craig, No 13, 23 Nov. 1808, Q97A, 107). In the years 18091810, when dissensions and opposition grew between Governor Craig and the

\footnotetext{
11 See for instance: Sydney to Parr, 8 March 1785, A107, 24; Sydney to Fanning, 30 Sept. 1787, RG7 G8D, volume 1, 110; Dundas to Dorchester, n¹, 2 Oct. 1793, Q77A, 67; Dundas to Dorchester, $\mathrm{n}^{\circ} 2$, 9 Nov 1793, Q77A, 76; Portland to Wentworth, $\mathrm{n}^{\circ}$ 7, 1 June 1795, A121, 186; Portland to Simcoe, $\mathrm{n}^{\circ}$ 10, 6 Jan. 1796, Q278A, 88; Hobart to Milnes, n8, 6 May 1802, Q78A, 185; Hobart to Wentworth, $\mathrm{n}^{\circ} 1,3$ Sept. 1801, A133, 133; Bathurst to Prevost, $\mathrm{n}^{\circ} 11,1$ Oct. 1812, Q125A, 70-71.
} 


\section{COLONIAL POLICIES AND PROPAGANDA: THE MAKING OF BRITISH NORTH} AMERICA AS AN ANTI-REPUBLICAN REFUGE

reformers in the assembly of Lower Canada, Lord Liverpool advised him, if no conciliatory grounds were to be found, to have a "strict and rigid" reading of the Canada Act - that would enable him to convene the assembly only once a year so as to oppose "a firm, temperate but persevering resistance to all the encroachments and usurpations of the Assembly" (Liverpool to Craig (confidential), 12 Sept. 1810, Q97A, 162-166). London adopted a similar attitude with regard to the foreign republican threat. The successive Secretaries of State continued to ask colonial officials to keep a watchful eye on foreigners that might "excite tumult and commotion" (Hobart to Milnes, No 3, 3 Dec. 1801, Q78A, 174; Camden to Milnes, No 1, 7 June 1804, Q78A, 131; Camden to Wentworth, No 5, 2 May 1805, A137, 17) but intervened directly when necessary. For instance, in 1812, in the midst of the Napoleonic Wars and a few months before the United States invaded Upper Canada, the Secretary of State, Lord Liverpool, limited the delivering of passports and attempted to prevent the landing of foreigners via the United States in all the Canadian colonies (circular letter, 21 March 1812, RG7 G8B, vol. 4, 263-264).

Therefore, to keep British North America safe from the United States and republicanism, London's policy to reform and develop the colonies was both pre-emptive and reactive; it was also severe and authoritarian, while proclaiming itself to be liberal. There was a clear design in London that was passed from minister to minister, regardless of the changes in the Cabinet, to ensure that the British North American colonies would be preserved from the risks and influence of both French and American republicanism.

\section{Immigration and emigration policies ${ }^{12}$}

Such an aim was also evident in the emigration and immigration policies designed for British North America. If the settling of the Loyalists set clear patterns for the accommodation of later refugees and exiles, London's determination to turn the colonies into a refuge from the United States and then to keep them sheltered from republican influence, often had ministers working on a tight rope. The question of American immigrants was extremely complicated as it was necessary to differentiate between bona fide Loyalists, American migrants who were fleeing the post-war chaos in the United States, and land-jobbers as well as smugglers who pretended to be loyal to the Crown for their own benefit. In the Maritimes, which received the largest influx of Loyalist refugees, ministers

\footnotetext{
12 The term "immigration" here is used to refer to settlers moving to British North America from areas outside of the British Empire, for example from the United States. The term "emigration" refers to migrations leaving Britain and encouraged by the British government, like that of the Highlanders.
} 


\section{ALICE LEMER-FLEURY}

were not willing to welcome Americans with open arms, contrary to the Lieutenant Governor in the colony. In New Brunswick, Carleton had "to prevent disloyal Persons from becoming settlers, which might endanger the Peace and Safety of the Province" (Sydney to Carleton, 21 Aug. 1784, RG7 G8B) while in Nova Scotia the British government demanded that British officials be more careful because American merchants were smuggling under pretence of immigration (Sydney to Gov of Nova Scotia, 27 Aug. 1785, A107, 175-176). Sydney also put a stop to the immigration of American settlers who were not United Empire Loyalists and insisted that new settlers take the Oath of Allegiance (Sydney to Parr, 20 Apr. 1786, A108, 100-102; Sydney to Parr, 20 Sept. 1787, A108, 134-136).

The problem was thornier in Upper Canada. The western part of the old province of Quebec had been a refuge for a few thousands Loyalists who had fled the United States but the province was still largely underdeveloped and under populated. To remedy this problem, the British Parliament passed an "Act for Encouraging New Settlers in His Majesty's Colonies and Plantations in America" in 1790 in order to attract settlers, notably from the United States (the Statutes... 1811, 374-375). This led the first Lieutenant Governor of Upper Canada, John Graves Simcoe, to issue a proclamation, circulated in the northern states of the new republic, to attract American settlers. ${ }^{13}$ This attempt can be seen as a prolongation of London's desire to create a refuge from the United States as Simcoe firmly believed that "many people in the new republic remained actively loyal to Great Britain." He was certain that most colonists must be dissatisfied with the chaotic government set up in the United States and that Upper Canada, now endowed with a British constitution, would attract the "sound elements in the American population" (CRAIG 1963, 20-21). Some of those "Late Loyalists" as they came to be called were not fleeing harassment or imprisonment like the first wave of refugees, but some were relatives of United Empire Loyalists while others came because they were disillusioned by the American republic (KNOWLES 2006, 36, 47). However, other colonial officials feared that the American settlers might not be "altogether destitute of the democratic principles which prevail in that country" (Solicitor General Gray, quoted in MARSHALL 2004, 40). This was also London's opinion, and Simcoe's enthusiasm was soon at odds with the viewpoint of the ministry. As early as 1792, in a long letter to the Lieutenant Governor, Henry Dundas tempered Simcoe's hopes to turn the province into a little Britain in a few years by attracting numerous American settlers, explaining that "in the very infancy of the Province [...] such emigrations

\footnotetext{
13 Potential settlers had to apply to the Governor or Lieutenant Governor, respect several requirements, among which an oath of allegiance to Great Britain.
} 


\section{COLONIAL POLICIES AND PROPAGANDA: THE MAKING OF BRITISH NORTH AMERICA AS AN ANTI-REPUBLICAN REFUGE}

would not be productive of [...] good consequences". The Secretary of State feared for the security, "regularity" and "stability" of Upper Canada and thus asked him to let American migrants come as they did then, and not "go out of [his] way to entice or allure them" (Dundas to Simcoe, 12 July 1792, Q278A, 9). In other words, keeping the colony safe from disorder and avoiding risks of dissent, or worse, mattered more than a speedier development of the colony. In later years, as colonial elites started to grow more nervous towards the perceived risks of sedition and republicanism, London tightened its stance on immigration from the United States. In Lower Canada (and later on in Upper Canada) the setting up of commissions to examine the character and principles of persons proposing to become settlers was approved by London (Portland to Dorchester, No 7, 8 Nov. 1794, Q77A, 162). From 1795 onwards, the British government took steps to limit the influence of American settlers: only settlers who had been living in the province for over seven years could become members of the assembly. These restrictions were further applied to franchise in 1800 (GATES 1968, 35, 39-44, 98; MARSHALL 2004, 33-34).

Gradually, London's policy for the development and preservation of British North American turned away from American settlers to favour emigrants from Scotland. They encouraged, first quietly, and later more decidedly, the emigration of Scottish Highlanders believed to be conservative and loyal, while discouraging that of Irish settlers, thought to be unruly and turbulent (ERRINGTON 1987, 50). For example, in 1802, Lord Selkirk, a Scottish Earl, approached the British government for help with his settlement projects, for which he wished to recruit settlers in Ireland. The Secretaries of State Pelham and Hobart directed him to recruit Scottish families instead, for they were more "tractable" than the Irish ("Extract of Conversation with Lord Pelham respecting Irish Emigration", 2 Apr. 1802, Hobart to Selkirk, 30 July 1802, SPNAC 13902, 13851-13852). In the coming years, emigration plans sponsored by the British government would take shape, especially in 1804 with a project for a Canadian regiment to be raised in Scotland, and from 1813 on to settle Highlanders to strengthen the Upper Canadian frontier. ${ }^{14}$

In order to promote the development of the British North American colonies whilst keeping them protected from the menace of republicanism, ministers in London progressively changed their immigration and emigration policies for North America. These changes took longer to take shape but they did

\footnotetext{
${ }^{14}$ For more details on the British colonial policies regarding Scottish migrants in Canada, see my article «L'émigration écossaise vers l'Amérique du Nord britannique (c. 1783-1815) : vers une convergence des politiques du centre pour les périphéries », Études écossaises, n ${ }^{19}, 2017$ [online].
} 


\section{ALICE LEMER-FLEURY}

so in the same manner the political institutions were reformed: there was a design planned in London and although a degree of executive liberty was left to colonial officials, ministers kept on intervening to shape policies for British North America.

\section{Conclusion}

The study of the colonial correspondence after the American Revolution shows that London was determined to turn its remaining British colonies in North America into a refuge from the United States. To this end, it implemented a comprehensive set of exceptional measures designed to accommodate the Loyalists. These reactive decisions heralded profound changes in colonial policy and soon developed into pro-active long-term policies that aimed at developing the British North American colonies while keeping them safe from republicanism. Once London had provided for the immediate need of the Loyalists refugees, it endeavoured to build on this great influx of English-speaking settlers to turn British North America into a conservative stronghold protected from dangers of republicanism. In a combination of liberality and authoritarianism, the British government reformed the governance and immigration and emigration policies of the British North American colonies in an attempt to avoid the spreading of republican ideas.

The War of 1812 can be seen as a test for the efficiency of London's colonial policies for British North America. In the summer of 1812, the United States declared war on Britain and invaded Upper Canada. In order to "vindicate the American revolution", in June 1812, the Americans issued a proclamation addressed to the people of Canada to try to gain their support for the republican cause, promising emancipation from the "tyranny and oppression" of Britain (THOMPSON 2008, 19). Over the next two years, some settlers, including two members of the assembly of Upper Canada, joined the American side (CRAIG 1963, 72-81). Though these cases were rather rare, the colonists were at first found apathetic by the British authorities (BICKMAN 2012, 139-140). They nevertheless remained loyal to the British Crown and eventually defended their provinces. While some in the United States believed that the invasion of British North America would be "a mere matter of marching", for the Canadians, the War of 1812 "eventually became chapter two in their rejection of American republicanism" (THOMPSON 2008, 24). Britain's plans may thus at first have appeared successful. However, turning British North America into a place that would remain free from demands for reform was bound to fail. In the 1800s, the seeds of discontent slowly started to grow in the British colonies. In Upper and Lower Canada, reformers were becoming more vocal (HARE 1993; TAFT MANNING 1962) but the British authorities at home were assured by colonial 


\section{COLONIAL POLICIES AND PROPAGANDA: THE MAKING OF BRITISH NORTH}

AMERICA AS AN ANTI-REPUBLICAN REFUGE

officials that these were only the ideas of a handful of republican "desperados" (THOMPSON 2008, 51). Though it would be many more years until they would ripe into rebellion, demands for more power and representation for the people could be stalled but not stopped.

\section{Bibliography}

\section{Primary sources}

Board of Trade, BT5, volume 1-24, 1783-1815. The National Archives, London.

Colonial correspondance. National Archives Canada.

- CO42 volume 15 to 22 (1781-1821)

- Q (Upper and Lower Canada) - volumes 26 to 136A and 278 to 318A (17831816)

- A (Nova Scotia and Cape Breton) - volumes 105 to 155 (1784-1815)

- $\quad$ RG7 G8B (New Brunswick) - volumes 1 to 5 (1784-1820)

- RG7 G8D (Prince Edward's Island) - volumes 1 to 4 (1771-1817)

Definitive Treaty of Peace between the United States of America and his Britannic Majesty, 3 Sept. 1783. Library of Congress. https://memory.loc.gov/cgi$\underline{\text { bin/ampage } ? \text { collId }=11 \text { sl\&fileName }=008 / 11 s 1008 . \mathrm{db} \& \mathrm{recNum}=93}$

Home Office Correspondence HO42/75-76. The National Archives, London

Report concerning the Canadian Archives for the Year 1904. 1905. Ottawa: E. Dawson, printer to the King's Most Excellent Majesty. National Archives Canada.

Report concerning the Canadian Archives for the Year 1905. 1906. Ottawa: E. Dawson, printer to the King's Most Excellent Majesty. National Archives Canada.

Selkirk Papers - National Archives of Canada (SPNAC), MG19 E1

The Parliamentary History of England from the Earlier Period to the Year 1803, W. Cobbett, T.C. Hansard: London, volume xxiii (1782) to volume xxxvi (1803), available on www.googlebooks.com.

The Parliamentary Debates from the Year 1803 to the Present Time, T.C. Hansard: London, volume i (1803) to volume xxxi (1815) available on 


\section{ALICE LEMER-FLEURY}

www.googlebooks.com and on Westminster's database http://hansard.millbanksystems.com

The Statute at Large of England and of Great Britain, vol. XVII. 1811. Edited by John Raithby. London: John Eyre and Andrew Strachan.

\section{Secondary sources}

ALLEN, Robert S. 1992. His Majesty's Indian Allies: British Indian Policy in the Defence of Canada, 1774-1815. Toronto and Oxford: Dundern Press.

BANNISTER, Jerry and Liam RIORDAM (eds). 2012. The Loyal Atlantic: Remaking the British Atlantic in the Revolutionary Era. Toronto: University of Toronto Press.

BAYLY, C.A. 1989. Imperial Meridian: the British Empire and the Wold, 17801830. New York: Longman.

BICKMAN, Troy. 2012. The Weight of Vengeance: the United States, the British Empire, and the War of 1812. Oxford: Oxford University Press.

CONRAD, Margaret, and James HILLIER. 2010 ( $2^{\text {nd }}$ edition). Atlantic Canada: a History, Toronto: Oxford University Press.

CRAIG, Gerald M. 1963. Upper Canada: the Formative Years, 1784-1841. Toronto: McClelland and Stewart.

DUCHARME, Michel. 2010. Le Concept de liberté au Canada à l'époque des Révolutions atlantiques, 1776-1838. Montreal et Kingston: McGill-Queen's University Press.

ERRINGTON, Jane. 1987. The Lion, the Eagle and Upper Canada: A Developing Colonial Ideology. Kingston and Montreal: McGill-Queen's University Press.

FOURNIER, Marcel. 1995. Les Français au Québec, 1765-1865 : un mouvement migratoire méconnu. Québec : les éditions du septentrion.

GATES, Lillian F. 1968. Land Policies of Upper Canada. Toronto: University of Toronto Press.

GREENWOOD, F. Murray. 1993. Legacies of Fear, Law and Politics in Quebec in the Era of the French Revolution. Toronto: University of Toronto Press (ebook). 


\section{COLONIAL POLICIES AND PROPAGANDA: THE MAKING OF BRITISH NORTH AMERICA AS AN ANTI-REPUBLICAN REFUGE}

HARE, John. 1993. Aux Origines du parlementarisme québécois, 1791-1793. Québec : Septentrion.

HARLOW, Vincent. 1961. "The New Imperial System, 1783-1815", in The Cambridge History of the British Empire, volume II, 1783-1870, edited by HOLLAND ROSE, J et al, 131-188. Cambridge: Cambridge University Press.

HEIDLER, Stephen and HEIDLER, Jeanne. 2002. The War of 1812. Westport, Connecticut and London: Greenwood Press.

JASANOFF, Maya. 2008. "The Other Side of Revolution: Loyalists in the British Empire". The William and Mary Quarterly, Third Series, 65, no. 2 (April): 205232.

JASANOFF, Maya. 2010. "Revolutionary Exiles: the American Loyalists and the French Emigré Diaspora”. In The Age of Revolution in Global Context, c. 17601840, edited by ARMITAGE, David and Sanjay SUBRAHMANYAN, 37-58. Basington and New York: Palgrave Macmillan

JASANOFF, Maya. 2011. Liberty's Exiles: American Loyalists in the Revolutionary World. New York and Toronto: Alfred A. Knopf (ebook).

JOHNSON, Paul E. 2007. The Early American Republic, 1789-1829. New York and Oxford: Oxford University Press.

KNOWLES, Norman. 1997. Inventing the Loyalists: The Ontario Loyalist tradition and the Creation of Usable Pasts. Toronto: University of Toronto Press.

KNOWLES, Valerie. 2006. Strangers at Our Gate: Canadian Immigration and Immigration Policy, 1540-2007. Toronto: Dundern Press.

LACROIX, Jean-Michel. 2016. Histoire du Canada, des origines à nos jours. Paris : Éditions Tallendier.

LANCTOT, Gustave. 1967. Canada and the American Revolution, 1774-1783. Cambridge, Massachusetts: Harvard University Press.

LAUDY, Danielle. 1995. «Les politiques coloniales britanniques et le maintien de l'Ancien Régime au Bas-Canada, 1791-1832 ». Histoire, économie et société, $14^{\text {ème }}$ année, no. 1: 73-92.

MANCKE, Elizabeth. 1999. "Early Modern Imperial Governance and the Origins of Canadian Political Culture". Canadian Journal of Political Science 32, no. 1 (March): 3-20. 


\section{ALICE LEMER-FLEURY}

MARSHALL, Peter. 2004. "Americans in Upper Canada, 1791-1812: "Late Loyalists" or Early Immigrants?" In Canadian Migration Pattern, from Britain and North America, edited by MESSAMORE, Barbara J., 33-44. Ottawa: Ottawa University Press.

MARSHALL, P. J. 2015. Remaking the British Atlantic, the United States and the British Empire after American Independence. Oxford: Oxford University Press.

MILLS, David. 1988. Idea of Loyalty in Upper Canada, 1784-1850. Kingston and Montreal: McGill-Queen's University Press.

MILOBAR, David. 1990. "Conservative Ideology, Metropolitan Government and the Reform of Quebec, 1782-1791". The International History Review 12, no. 1 (February): 45-64.

NELSON, R.R. 1969. The Home Office, 1782-1801. Durham: Duke University Press.

POTTER, Janice. 1983. The Liberty We Seek. Loyalist Ideology in Colonial New York and Massachusetts. Cambridge, Massachusetts: Harvard University Press.

SHAMA, Simon. 2006. Rough Crossing: Britain, the Slaves and the American Revolution. Toronto: Viking Canada.

STUART, Reginald C. 1988. United States Expansionism and British North America, 1775-1871. Chapel Hill and London: the University of North Carolina Press.

TAFT MANNING, Helen. 1933. British Colonial Government after the American Revolution, 1782-1820. New Haven: Yale University Press.

TAFT MANNING, Helen. 1962. The Revolt of French Canada, 1800-1835: A Chapter of the History of the British Commonwealth. New York: St Martin's Press.

THOMPSON, John. 2008. Canada and the United States: Ambivalent Allies. Athens: University of Georgia Press.

WRONG, George M. 1968. Canada and the American Revolution: the Disruption of the First British Empire. New York: Macmillan.

YOUNG, D.M. 1961. The Colonial Office in the Early Nineteenth Century. London: Longman. 